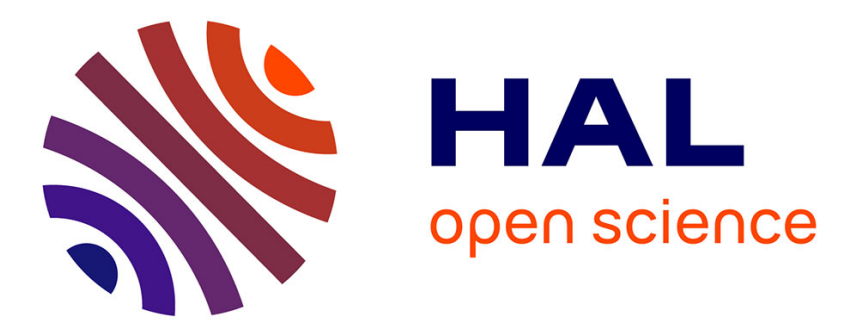

\title{
Chalara fraxinea is an invasive pathogen in France
}

Claude Husson, Bruno Scala, Olivier Caël, Pascal Frey, Nicolas Feau, Renaud Ioos, Benoit Marçais

\section{To cite this version:}

Claude Husson, Bruno Scala, Olivier Caël, Pascal Frey, Nicolas Feau, et al.. Chalara fraxinea is an invasive pathogen in France. European Journal of Plant Pathology, 2011, 130 (3), pp.311-324. 10.1007/s10658-011-9755-9 . hal-01136967

\section{HAL Id: hal-01136967 https://hal.science/hal-01136967}

Submitted on 30 Mar 2015

HAL is a multi-disciplinary open access archive for the deposit and dissemination of scientific research documents, whether they are published or not. The documents may come from teaching and research institutions in France or abroad, or from public or private research centers.
L'archive ouverte pluridisciplinaire HAL, est destinée au dépôt et à la diffusion de documents scientifiques de niveau recherche, publiés ou non, émanant des établissements d'enseignement et de recherche français ou étrangers, des laboratoires publics ou privés. 


\section{Chalara fraxinea is an invasive pathogen in France}

\author{
Claude Husson • Bruno Scala • Olivier Caël • \\ Pascal Frey $•$ Nicolas Feau $•$ Renaud Ioos • \\ Benoît Marçais
}

\begin{abstract}
Decline induced by Chalara fraxinea is an emerging disease that severely affects ash stands in Europe. The disease appears to have an invasive spread from East to West of Europe in the last decade. The teleomorphic stage, Hymenoscyphus pseudoalbidus, that occurs as apothecia on ash rachis in the litter was recently described. The origin of ash decline remains unclear as a cryptic species, $H$. albidus, a long-established fungus in Europe, could be present in the same niche, and as in Switzerland, H. pseudoalbidus was shown to have been present long before the recent epidemic outbreak. In France, the emerging disease is very recent and clearly restrained to Northeastern France. We thus collected isolates from infected hosts and from apothecia/ash rachis both inside and outside the infected area in
\end{abstract}

C. Husson $(\bowtie) \cdot$ B. Scala $\cdot$ O. Caël $\cdot$ P. Frey $\cdot$ B. Marçais INRA, Nancy Université,

UMR 1136 Interactions Arbres/Microorganismes,

IFR110,

54280 Champenoux, France

e-mail: claude.husson@nancy.inra.fr

N. Feau

INRA, UMR 1202 BIOGECO,

69 route d'Arcachon,

33612 Cestas Cedex, France

R. Ioos

Anses, Laboratoire de la Santé des Végétaux,

Unité de Mycologie,

IFR110, Domaine de Pixérécourt,

54220 Malzéville, France
France in order to compare them on the basis of pathogenicity towards ash seedlings and sequences of the ITS regions and of three single-copy genes. We showed that two population types exhibiting about $2 \%$ base pair polymorphism in the sequences analysed were present in Northern France. The first type, corresponding to $H$. pseudoalbidus, was present on rachis and infected hosts only in Northeastern France and showed strong pathogenicity towards ash seedlings in inoculation tests. By contrast, the second type, which corresponds to $H$. albidus, was present throughout Northern France and showed no pathogenicity towards ash seedlings. Our study confirms the results of Queloz et al. (2010) who presented molecular evidences for the existence of two cryptic species, $H$. albidus and $H$. pseudoalbidus. The results strongly suggest that Chalara fraxinea/ H. pseudoalbidus is a recent invader in France.

Keywords Ash · Emerging disease · Hymenoscyphus · Pathogenicity · Single-copy genes . Real-time PCR

\section{Introduction}

Emerging infectious diseases can be caused by invasion of an exotic pathogen, changes in host and/ or environmental conditions favouring the disease, or evolutionary changes in the pathogen population. Introduced pathogens have been shown to be a major 
cause of the emergence of plant diseases (Anderson et al. 2004; Desprez-Loustau et al. 2007; Desprez-Loustau et al. 2010). Among well known cases in natural ecosystems are Cryphonectria parasitica on chestnut (Anagnostakis 1987) or Phytophthora cinnamomi on eucalyptus in Australia (Weste and Marks 1987). The role of changes in environmental conditions and in particular in climate also starts to be well documented. Examples are the increase in P. cinnamomi induced-canker on oak in France (Marçais et al. 2004) or the emergence of Dothistroma needle blight on pine in British Columbia (Woods et al. 2005). Finally, hybridization of indigenous or cryptic species can lead to emerging diseases. Phytophthora alni subsp. alni that has spread in European riparian forests and killed numerous alders during the last two decades was shown to be the result of several hybridizations between $P$. alni subsp. uniformis and $P$. alni subsp. multiformis (Ioos et al. 2006).

Since the early 1990s, a new emerging lethal disease has reached epidemic levels on ash in Central Europe (Kowalski 2006; Bakys et al. 2009). The causal agent, Chalara fraxinea T. Kowalski (anamorphic stage), firstly described in Poland, is responsible of a severe decline on all age classes of Fraxinus excelsior (Kowalski 2006). Symptoms are variously coloured (brownish to orange) bark necroses and cankers without exudates on stems and branches, leading to dieback of trees (Kowalski 2006; Schumacher et al. 2010). Development of molecular tools designed in the Internal Transcribed Spacer sequences (ITS) of the nuclear ribosomal RNA cistrons for detecting $C$. fraxinea was recently performed (Chandelier et al. 2010; Ioos et al. 2009; Johansson et al. 2010). In addition, the ascomycete Hymenoscyphus albidus, a common fungus found as apothecia on the ash rachis of the litter throughout Europe (Desmazières 1851), was firstly proposed to be the teleomorph of Chalara fraxinea following culturing from ascospores, morphological comparisons of apothecia between herbarium specimens and collected samples, and comparison of ITS sequences from $C$. fraxinea isolates and apothecia collected in infected stands (Kowalski and Holdenrieder 2009).

However, Queloz et al. (2010) showed that H. albidus and the teleomorph of $C$. fraxinea are two cryptic but distinct species based on sequences of three loci and designated Hymenoscyphus pseudoalbidus sp. nov. as the teleomorphic stage of $C$. fraxinea. As this new species was detected in Swiss herbarium samples collected at least 30 years prior to the outbreak of the epidemic (Queloz et al. 2010), the origin of H. pseudoalbidus remains enigmatic and the recent emergence of ash decline needs to be clarified.

In France, emergence of the disease is very recent as the first $H$. pseudoalbidus associated ash declines were observed in 2008 (Ioos et al. 2009). Until now, the disease is only located in Northeastern France and the margin of the infected area is well known due to a precise survey performed in 2009 by the French forest health survey service (Département de la Santé des Forêts, DSF). Thus, the situation in France is particularly suitable for studying the emergence of $H$. pseudoalbidus and its causes and for confirming the cryptic speciation in $H$. albidus as suggested by Queloz et al. (2010).

Our aim was thus to collect isolates from infected hosts or apothecia/rachis both inside and outside the infected area and to compare them for pathogenicity towards ash seedlings. In order to clarify the role of a possible population change in the disease emergence, comparisons were also made based on ITS and single-copy genes sequence data.

\section{Material and methods}

Study sites and sampling

Two regions were selected: (i) Northeastern France where severe decline associated with $H$. pseudoalbidus has been observed (referred to as "within focus", WF); (ii) Western and Central France where no symptoms associated with $H$. pseudoalbidus were recorded so far (referred to as "out of the focus", OF). Several sites were selected within each region (Table 1, Fig. 1a). Half of the WF sites selected were young regenerations of Fraxinus excelsior (stands originating from natural seeding of local mature trees) heavily infected by H. pseudoalbidus and reported in the DSF database. In each site, in 2009, a 10-20 cm long stem section containing the lesion boundaries was sampled from about 10 young ash seedlings with symptoms of H. pseudoalbidus. The samples were placed in plastic bags and brought back to the laboratory for analysis.

The other WF sites were either 2 to 7-year-old plantations or mature stands of $F$. excelsior with 


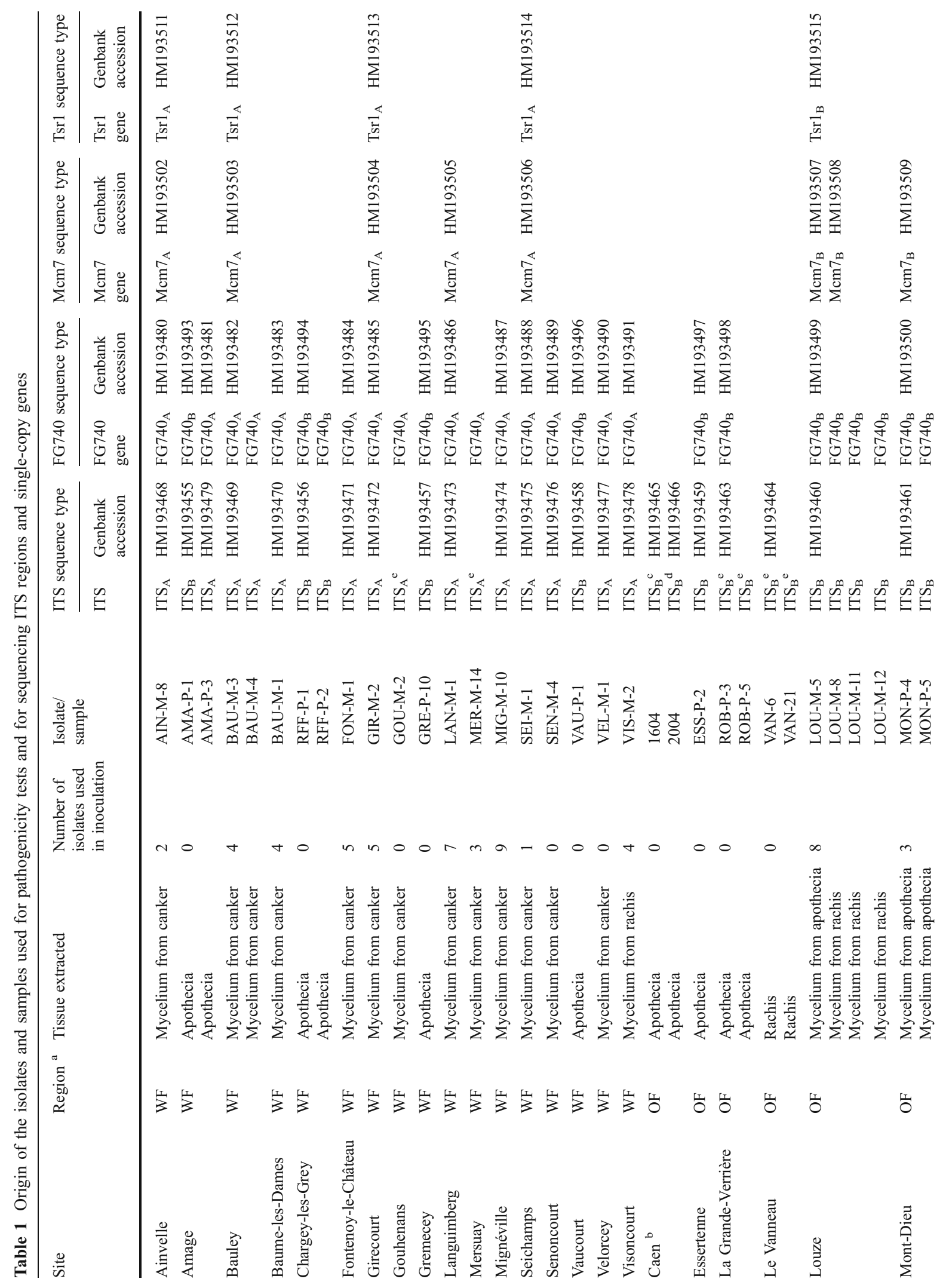


presence of both $H$. pseudoalbidus symptoms on seedlings and apothecia on ash rachis in the litter. All the $\mathrm{OF}$ sites corresponded to mature $F$. excelsior in forest or hedge situations under which Hymenoscyphus sp. apothecia were found on ash rachis in the litter. In both these WF and OF sites harvested in 2009, 5-20 ash rachis with apothecia were sampled from the litter at the foot of young or mature trees, placed in plastic bags and brought back to the laboratory for further processing.

Several herbarium specimens were added to the study including the $H$. pseudoalbidus reference strain No. 2112 collected in Poland, identified and provided by T. Kowalski. Three additional specimens of $H$. albidus apothecia were kindly provided by JeanPhilippe Rioult, from the Caen Herbarium (CN)Université de Caen Basse-Normandie (UCBN). The first specimen named ThD0207254370 was collected in Saint-Gatien-des-Bois (Normandy, Northwestern France) in 2002. The two other herbarium specimens correspond to the $H$. albidus type specimens collected by Roberge in 1850 from the Bois de Lébisey, close to Caen and used for the species description (specimens No. 1604 and 2004 in Plantes Cryptogames de France, Desmazières 1851).

Isolation procedures

Isolation of Hymenoscyphus sp. either from rachis or canker was undertaken as described by Kowalski (2006). Briefly, a 2-4 cm stem section containing the lesion margin or 3-4 cm long rachis pieces were surface sterilised (1 $\mathrm{min}$ in $90 \%$ ethanol, $5 \mathrm{~min}$ in $4 \% \mathrm{NaOCl}$ and $30 \mathrm{~s}$ in $90 \%$ ethanol). Then, small pieces of wood sampled at the lesion margin or 3-6 $\mathrm{mm}$ long rachis pieces located directly under the apothecia were placed on malt agar supplemented with antibiotic (20 $\mathrm{g} \mathrm{l}^{-1}$ malt extract, $100 \mathrm{mg} \mathrm{l^{-1 }}$ streptomycin and $15 \mathrm{~g} \mathrm{l}^{-1}$ agar). Whenever isolation from rachis was unsuccessful, culture of fungus was performed from ascospores as follows: apothecia were fixed, disc downwards, on the lid inside a Petri dish containing malt agar supplemented with antibiotic in order to discharge ascospores onto the media. Dishes were daily checked using a binocular microscope and ascospores were collected and transferred in a new Petri dish for culturing as soon as observed.

The Petri dishes were incubated at $20^{\circ} \mathrm{C}$ in the dark and any isolate morphologically similar to 


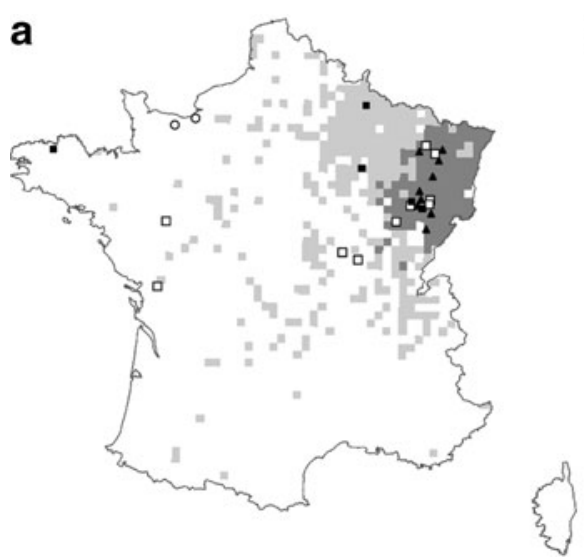

Fig. 1 Distribution of Hymenoscyphus pseudoalbidus symptoms in France and sites sampled (source Département de la Santé des Forêts, DSF). White area, no observation; light grey, area surveyed but no $H$. pseudoalbidus associated symptoms reported; dark grey, H. pseudoalbidus detected by PCR from affected ash trees. A. Sites sampled for isolate collection: $\square$, Isolates from apothecia on ash rachis from the litter, $\boldsymbol{\Delta}$, Isolates from diseased ash twigs. Closed

Hymenoscyphus sp. (i.e. septate white mycelium without clumps) that emerged from the wood, rachis pieces or ascospores was transferred onto a new malt agar Petri dish. Putative Hymenoscyphus sp. isolates were then assayed with both the real-time PCR test developed by Ioos et al. (2009) and the one developed in this study (see below). From 1 to 9 Hymenoscyphus sp. isolates per site were kept on malt agar for further analyses (Table 1).

\section{Pathogenicity test}

Eighty-one one-year-old $80-100 \mathrm{~cm}$ high seedlings of Fraxinus excelsior were transplanted to 10-litre plastic pots in a 50:50 sand-peat mixture in April 2009 and then grown in a glasshouse until inoculation. The substrate was supplemented with $\mathrm{CaCO} 3\left(2 \mathrm{~g} \mathrm{l}^{-1}\right)$ and a controlled release fertilizer, Nutricote ${ }^{\circledR} 13-13-13$ (3 $\left.\mathrm{g} \mathrm{l}^{-1}\right)$. In October 2009, seedlings were inoculated with Hymenoscyphus sp. isolates (either from canker or rachis/apothecia) originating from WF or OF sites. Since the aim was to compare the aggressiveness of fungal populations from WF vs. OF sites and not to characterize specific isolates, seedlings were inoculated with different isolates, but no or only few replicates per isolate. Altogether, 66 ash seedlings were inoculated, i.e. 22 with 14 isolates from 3 OF sites

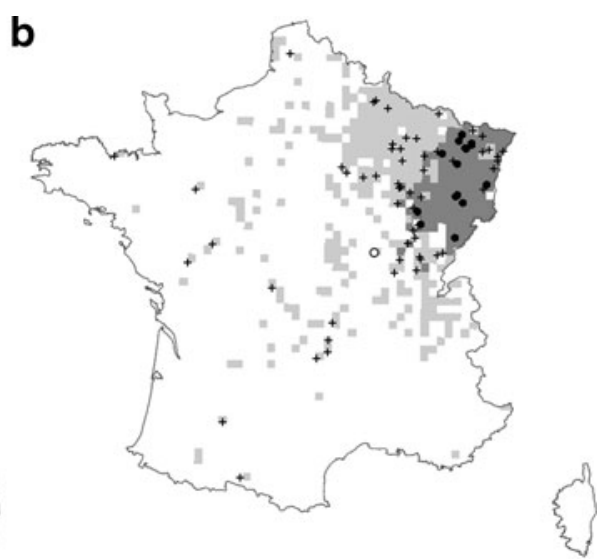

symbols are isolates that were used for inoculation. $\circ$, Apothecia samples from herbarium (Herbier de Caen - Université de Caen Basse-Normandie). B. DSF survey sites re-analysed using the newly developed Halb-F-/-R/-P primer / probe set specific of ITS $_{\mathrm{B}}$ : $\bullet$ Positive with Cfrax-F-/-R/-P and negative with Halb-F-/-R/-P; O Negative with Cfrax-F-/-R/-P and positive with Halb-F-/-R/-P; (+) negative with both primer / probe set

and 44 with 44 isolates from 10 WF sites (Table 1). Isolates from Louze (OF site) were inoculated on 2 ash seedlings, while all the remaining isolates were inoculated only on one seedling. Inoculation was performed as follows: Pieces of wood $(1 \times 1 \times 15 \mathrm{~mm})$ were cut from an ash seedling, sterilized twice for $20 \mathrm{~min}$ at $120^{\circ} \mathrm{C}$, and then placed onto a fresh fungal colony grown on malt agar $\left(20 \mathrm{~g} \mathrm{l}^{-1}\right.$ malt extract, $15 \mathrm{~g} \mathrm{l}^{-1}$ agar). After 1 month incubation in the dark at $20^{\circ} \mathrm{C}$, the colonized pieces of wood were used to inoculate the ash seedlings on the 14 October 2009. The last growth unit of the seedling was wounded down to the wood on $1 \mathrm{~cm}$ long using a sterilized scalpel. A colonized piece of wood was inserted in the wound which was then sealed with a parafilm strip. An additional set of 8 seedlings were inoculated with a sterilized ash wood piece incubated onto malt agar as negative control. Four months after inoculation, on the 10 February 2010, the seedlings were cut for analysis. The length and width of the bark lesion at the cambium level were measured for each seedling.

In order to study the difference in aggressiveness between WF and OF fungal populations, an analysis of variance on the log-transformed lesion length was performed including a site effect nested within site type effect (WF/OF). 


\section{DNA extraction}

DNA extractions were performed using the DNeasy Plant mini-kit (Qiagen, Courtaboeuf, France), most of them from approximately $100 \mathrm{mg}$ of fresh mycelium grown on Petri dishes. Whenever the pathogen was not successfully isolated from the rachis, DNA was extracted directly from the rachis or the apothecia. This was also the case for the three herbarium specimens of $H$. albidus.

DNA was extracted following the manufacturer's instructions, except for the three herbarium specimens for which the protocol was modified as follows: samples were placed in a 2-ml Eppendorf tube, cooled to $-20^{\circ} \mathrm{C}$ for $10 \mathrm{~min}$ and then ground for $30 \mathrm{~s}$ with one 3-mm tungsten carbide bead at a frequency of $30 \mathrm{~Hz}$, using a mixer mill grinder (TissueLyser, Qiagen, France). AP1 buffer (supplied by the manufacturer) was added and samples were ground again for $30 \mathrm{~s}$. Incubation period with AP1 buffer was extended to $3 \mathrm{~h}$ at $55^{\circ} \mathrm{C}$. The wash step was repeated three times. Finally, the elution volume was reduced to $80 \mu \mathrm{l}$ instead of $200 \mu$ l.

Conventional PCRs and design of primers for real-time PCR

PCR amplifications of the ITS regions with universal primer pairs ITS1/ITS4 (White et al. 1990) and ITS1F/ITS4 (Gardes and Bruns 1993) were performed in $20 \mu \mathrm{l}$ reaction volumes consisting of ultra-pure water, $1 \mathrm{X}$ reaction buffer, $1.5 \mathrm{mM} \mathrm{MgCl}_{2}, 0.2 \mathrm{mM}$ of each dNTP, $0.2 \mu \mathrm{M}$ of each primer, $0.7 \mathrm{U}$ of $\mathrm{Taq}$ Polymerase (Sigma-Aldrich, L'Isle d'Abeau, France) and $2 \mu \mathrm{l}$ of template DNA. PCR reactions were carried out on a PTC-200 Peltier thermal cycler (MJ Research) or a GeneAmp PCR System 9700 (Applied Biosystems). For both assays, the PCR cycling conditions included an initial denaturation step for $3 \mathrm{~min}$ at $95^{\circ} \mathrm{C}$ followed by 35 cycles for $15 \mathrm{~s}$ at $95^{\circ} \mathrm{C}$, annealing for $30 \mathrm{~s}$ at $50^{\circ} \mathrm{C}$, elongation for $80 \mathrm{~s}$ at $72^{\circ} \mathrm{C}$ and a final elongation step for $10 \mathrm{~min}$ at $72^{\circ} \mathrm{C}$. All PCR products were visualized by ultra-violet fluorescence following 1\% agarose gel electrophoresis in $1 \mathrm{X}$ TBE buffer and ethidium bromide staining. Amplified ITS regions were then sequenced by Cogenics (Beckman Coulter Genomics, Grenoble, France) and aligned using Sequencher ${ }^{\circledR} 4.7$ (Gene Codes Corporation, USA). GenBank accession numbers are listed in Table 1.
Amplified ITS regions from isolates collected in WF (from symptomatic seedlings, rachis or apothecia) or OF sites (from rachis or apothecia), were compared by multiple alignments. As we detected two strikingly different ITS sequences (thereafter referred to as ITS $_{\mathrm{A}}$ and $\mathrm{ITS}_{\mathrm{B}}$ ) in the studied Hymenoscyphus sp. populations, the real-time PCR assay designed by Ioos et al. (2009) proved insufficient for the diagnostic/detection of all isolates encountered (detection of only the ITS $_{\mathrm{A}}$ type). We thus developed a new real-time PCR assay to specifically detect isolates with the $\mathrm{ITS}_{\mathrm{B}}$ type. Based on alignment of ITS $_{\mathrm{A}}$, ITS $_{\mathrm{B}}$ and the $H$. fructigenus ITS sequences, a pair of primers Halb-F/Halb-R and a dual-labelled probe Halb-P were designed by using the Primer3 software (Rozen and Skaletsky 2000) for detecting specifically ITS $_{B}$. The specificity of Halb-F/-R/-P was checked with a collection of WF and OF $H$. albidus isolates and a collection of European saprotrophic or endophytic fungi either phylogenetically close to H. albidus or sharing the same ecological niche i.e. Fraxinus excelsior (Table 2). Moreover, since multiple amplified ITS sequences were obtained by using universal primer pairs ITS1F/ITS4 from some apothecia or rachis DNA extracts, a new set of primers for conventional PCR, CHA-F1/CHA-R2 was designed as described before in order to amplify specifically both ITS $_{\mathrm{A}}$ and ITS $_{\mathrm{B}}$.

In addition, the FG740 single-copy gene sequence was used to compare the WF and OF isolates. This gene was selected among the 246 genes of the FUNYBASE database (Aguileta et al. 2008; Marthey et al. 2008; http://genome.jouy.inra.fr/funybase/), using a multistep procedure implemented in the PHYLORPH program (Feau 2010). Briefly, PHYLORPH identified the single copy orthologs of the 246 proteins of FUNYBASE in the full genome sequences of three fungi closely related to $H$. albidus (i.e. Blumeria graminis f. sp. hordei, Sclerotinia sclerotiorum and Botrytis cinerea) and three others more distantly related (Magnaporthe grisea, Neurospora crassa and Fusarium graminearum). Multiple DNA alignments were then generated for each group of orthologs, and only those which contained (i) DNA-level differences potentially useful in phylogenetic analyses and (ii) conserved regions to obtain successful and reliable PCR amplifications (and subsequent DNA sequencing), were retained. Based on these predictions, a pair of degenerate primers FG740-F/FG740-R was 
Table 2 Characteristics of the isolates and samples tested in this study and results of the real-time PCR assay using primers/probe Halb-F/-R/-P developed in this study and Cfrax-F/-R/-P developed by Ioos et al. (2009)

\begin{tabular}{|c|c|c|c|c|c|c|c|}
\hline Species & Isolate/sample & Tissue extracted & Origin & Provider & $\begin{array}{l}\text { RT-PCR } \\
\text { using } \\
\text { Cfrax-F/-R/-P }\end{array}$ & $\begin{array}{l}\text { RT-PCR } \\
\text { using } \\
\text { Halb-F/-R/-P }\end{array}$ & $\begin{array}{l}\text { ITS } \\
\text { sequence } \\
\text { type }\end{array}$ \\
\hline $\begin{array}{l}\text { Hymenoscyphus } \\
\text { albidus }\end{array}$ & PLE-P1 & $\begin{array}{l}\text { Mycelium from } \\
\text { apothecia }\end{array}$ & France (Côte d'Armor) & INRA & - & + & $\operatorname{ITS}_{\mathrm{B}}$ \\
\hline H. albidus & LOU-M-4 & $\begin{array}{l}\text { Mycelium from } \\
\text { apothecia }\end{array}$ & France (Haute-Marne) & INRA & - & + & $\mathrm{ITS}_{\mathrm{B}}$ \\
\hline H. albidus & LOU-M-5 & $\begin{array}{l}\text { Mycelium from } \\
\text { apothecia }\end{array}$ & France (Haute-Marne) & INRA & - & + & $\operatorname{ITS}_{\mathrm{B}}$ \\
\hline H. albidus & LOU-M-33 & $\begin{array}{l}\text { Mycelium from } \\
\text { rachis }\end{array}$ & France (Haute-Marne) & INRA & - & + & $\operatorname{ITS}_{\mathrm{B}}$ \\
\hline H. albidus & ANG-8 & Rachis & $\begin{array}{l}\text { France } \\
\text { (Maine-et-Loire) }\end{array}$ & INRA & - & + & $\operatorname{ITS}_{\mathrm{B}}$ \\
\hline H. albidus & VAN-6 & Rachis & $\begin{array}{l}\text { France } \\
\quad \text { (Maine-et-Loire) }\end{array}$ & INRA & - & + & $\operatorname{ITS}_{\mathrm{B}}$ \\
\hline H. albidus & ESS-P-1 & Apothecia & France (Saône-et-Loire) & INRA & - & + & $\mathrm{ITS}_{\mathrm{B}}$ \\
\hline H. albidus & ESS-P-2 & Apothecia & France (Saône-et-Loire) & INRA & - & + & $\operatorname{ITS}_{\mathrm{B}}$ \\
\hline H. albidus & AMA-P-1 & Apothecia & France (Haute-Saône) & INRA & - & + & $\operatorname{ITS}_{\mathrm{B}}$ \\
\hline H. albidus & GRE-P-4 & Apothecia & France (Moselle) & INRA & - & + & $\operatorname{ITS}_{\mathrm{B}}$ \\
\hline H. albidus & GRE-P-5 & Apothecia & France (Moselle) & INRA & - & + & $\operatorname{ITS}_{\mathrm{B}}$ \\
\hline H. albidus & GRE-P-10 & Apothecia & France (Moselle) & INRA & - & + & $\mathrm{ITS}_{\mathrm{B}}$ \\
\hline H. albidus & VAU-P-1 & Apothecia & $\begin{array}{l}\text { France } \\
\text { (Meurthe-et-Moselle) }\end{array}$ & INRA & - & + & $\operatorname{ITS}_{\mathrm{B}}$ \\
\hline H. albidus & VAU-P-2 & Apothecia & $\begin{array}{l}\text { France } \\
\text { (Meurthe-et-Moselle) }\end{array}$ & INRA & - & + & $\mathrm{ITS}_{\mathrm{B}}$ \\
\hline H. albidus & RFF-P-1 & Apothecia & France (Haute-Saône) & INRA & - & + & $\operatorname{ITS}_{\mathrm{B}}$ \\
\hline H. albidus & RFF-P-2 & Apothecia & France (Haute-Saône) & INRA & - & + & $\operatorname{ITS}_{\mathrm{B}}$ \\
\hline H. albidus & ROB-P-4 & Apothecia & France (Saône-et-Loire) & INRA & - & + & $\mathrm{ITS}_{\mathrm{B}}$ \\
\hline H. albidus & ROB-P-5 & Apothecia & France (Saône-et-Loire) & INRA & - & + & $\operatorname{ITS}_{\mathrm{B}}$ \\
\hline H. albidus & 1604 & Apothecia & France (Calvados) & Herbier de Caen & - & + & $\operatorname{ITS}_{\mathrm{B}}$ \\
\hline H. albidus & 2004 & Apothecia & France (Calvados) & Herbier de Caen & - & + & $\operatorname{ITS}_{\mathrm{B}}$ \\
\hline H. albidus & ThD0207254370 & Apothecia & France (Calvados) & Herbier de Caen & - & + & $\operatorname{ITS}_{\mathrm{B}}$ \\
\hline H. fructigenus & GRE-P-3 & $\begin{array}{l}\text { Apothecia on } \\
\text { acorn }\end{array}$ & $\begin{array}{l}\text { France } \\
\text { (Meurthe-et-Moselle) }\end{array}$ & INRA & n.a. & - & ITSfru \\
\hline H. fructigenus & GRE-P-14 & $\begin{array}{l}\text { Apothecia on } \\
\text { acorn }\end{array}$ & $\begin{array}{l}\text { France } \\
\text { (Meurthe-et-Moselle) }\end{array}$ & INRA & n.a. & - & ITSfru \\
\hline H. fructigenus & GRE-P-15 & $\begin{array}{l}\text { Apothecia on } \\
\text { acorn }\end{array}$ & $\begin{array}{l}\text { France } \\
\text { (Meurthe-et-Moselle) }\end{array}$ & INRA & n.a. & - & ITSfru \\
\hline $\begin{array}{l}\text { Hymenoscyphus } \\
\text { pseudoalbidus }\end{array}$ & AMA-P-3 & Apothecia & France (Haute Saône) & INRA & + & - & $\operatorname{ITS}_{\mathrm{A}}$ \\
\hline H. pseudoalbidus & AMA-P-10 & Apothecia & France (Haute Saône) & INRA & + & - & $\operatorname{ITS}_{\mathrm{A}}$ \\
\hline H. pseudoalbidus & VYF-P-2 & Apothecia & France (Haute Saône) & INRA & + & - & $\mathrm{ITS}_{\mathrm{A}}$ \\
\hline H. pseudoalbidus & AIN-M-8 & $\begin{array}{l}\text { Mycelium from } \\
\text { canker }\end{array}$ & France (Haute Saône) & INRA & + & - & $\operatorname{ITS}_{\mathrm{A}}$ \\
\hline H. pseudoalbidus & BAU-M-1 & $\begin{array}{l}\text { Mycelium from } \\
\text { canker }\end{array}$ & France (Doubs) & INRA & + & - & $\operatorname{ITS}_{\mathrm{A}}$ \\
\hline H. pseudoalbidus & LAN-M-1 & $\begin{array}{l}\text { Mycelium from } \\
\text { canker }\end{array}$ & France (Moselle) & INRA & + & - & $\mathrm{ITS}_{\mathrm{A}}$ \\
\hline H. pseudoalbidus & FON-M-2 & $\begin{array}{l}\text { Mycelium from } \\
\text { canker }\end{array}$ & France (Vosges) & INRA & + & - & $\operatorname{ITS}_{\mathrm{A}}$ \\
\hline H. pseudoalbidus & GIR-M-2 & $\begin{array}{l}\text { Mycelium from } \\
\text { canker }\end{array}$ & France (Vosges) & INRA & + & - & $\mathrm{ITS}_{\mathrm{A}}$ \\
\hline H. pseudoalbidus & GOU-M-2 & $\begin{array}{l}\text { Mycelium from } \\
\text { canker }\end{array}$ & France (Haute-Saône) & INRA & + & - & $\operatorname{ITS}_{\mathrm{A}}$ \\
\hline H. pseudoalbidus & SEN-M-4 & $\begin{array}{l}\text { Mycelium from } \\
\text { canker }\end{array}$ & France (Haute-Saône) & INRA & + & - & $\operatorname{ITS}_{\mathrm{A}}$ \\
\hline H. pseudoalbidus & 2112 & $\begin{array}{l}\text { Mycelium from } \\
\text { canker }\end{array}$ & Poland (Stary Sącz) & T. Kowalski & + & - & $\operatorname{ITS}_{\mathrm{A}}$ \\
\hline Alternaria alternata & 2401 & Mycelium & Poland (Stary Sącz) & T. Kowalski & $-{ }^{\mathrm{a}}$ & - & n.a. \\
\hline Alternaria sp. & 2498 & Mycelium & Poland (Stary Sącz) & T. Kowalski & $-^{\mathrm{a}}$ & - & n.a. \\
\hline Alternaria sp. & $08-554 \mathrm{~b}$ & Mycelium & France (Haute Saône) & R. Ioos & $-{ }^{\mathrm{a}}$ & - & n.a. \\
\hline
\end{tabular}


Table 2 (continued)

\begin{tabular}{|c|c|c|c|c|c|c|c|}
\hline Species & Isolate/sample & Tissue extracted & Origin & Provider & $\begin{array}{l}\text { RT-PCR } \\
\text { using } \\
\text { Cfrax-F/-R/-P }\end{array}$ & $\begin{array}{l}\text { RT-PCR } \\
\text { using } \\
\text { Halb-F/-R/-P }\end{array}$ & $\begin{array}{l}\text { ITS } \\
\text { sequence } \\
\text { type }\end{array}$ \\
\hline Cytospora sp. & 2256.1 & Mycelium & Poland (Rokita) & T. Kowalski & $-{ }^{\mathrm{a}}$ & - & n.a. \\
\hline Cytospora $\mathrm{sp}$ & $08-483.8$ & Mycelium & France (Haute Saône) & R. Ioos & $-^{\mathrm{a}}$ & - & n.a. \\
\hline Diplodia mutila & 1880 & Mycelium & Poland (Miechow) & T. Kowalski & $-^{\mathrm{a}}$ & - & n.a. \\
\hline Epicoccum nigrum & $08-483.3$ & Mycelium & France (Haute Saône) & R. Ioos & $-^{\mathrm{a}}$ & - & n.a. \\
\hline Fusarium avenaceum & 2283 & Mycelium & Poland (Rokita) & T. Kowalski & $-^{\mathrm{a}}$ & - & n.a. \\
\hline Fusarium avenaceum & 2629 & Mycelium & Poland (Miechow) & T. Kowalski & $-^{\mathrm{a}}$ & - & n.a. \\
\hline Fusarium avenaceum & 2386 & Mycelium & Poland (Stary Sącz) & T. Kowalski & $-^{\mathrm{a}}$ & - & n.a. \\
\hline Fusarium avenaceum & 2626 & Mycelium & Poland (Miechow) & T. Kowalski & $-^{\mathrm{a}}$ & - & n.a. \\
\hline Fusarium equiseti & $08-472$ & Mycelium & France (Haute Saône) & R. Ioos & $-^{\mathrm{a}}$ & - & n.a. \\
\hline Fusarium lateritium & 2623 & Mycelium & Poland (Miechow) & T. Kowalski & $-^{\mathrm{a}}$ & - & n.a. \\
\hline Fusarium oxysporum & $08-411 b$ & Mycelium & France (Haute Saône) & R. Ioos & $-^{\mathrm{a}}$ & - & n.a. \\
\hline Fusarium oxysporum & $08-554 a$ & Mycelium & France (Haute Saône) & R. Ioos & $-^{\mathrm{a}}$ & - & n.a. \\
\hline Fusarium semitectum & $08-976$ & Mycelium & France (Haute Saône) & R. Ioos & $-^{\mathrm{a}}$ & - & n.a. \\
\hline Fusarium solani & $08-411 \mathrm{c}$ & Mycelium & France (Haute Saône) & R. Ioos & $-^{\mathrm{a}}$ & - & n.a. \\
\hline $\begin{array}{l}\text { Geniculosporium } \\
\text { serpens }\end{array}$ & 2493 & Mycelium & Poland (Stary Sącz) & T. Kowalski & $-^{\mathrm{a}}$ & - & n.a. \\
\hline Phomopsis sp. & 1942.1 & Mycelium & Poland (Ojcow) & T. Kowalski & $-^{\mathrm{a}}$ & - & n.a. \\
\hline Phomopsis sp. & 1601.1 & Mycelium & Poland (Ojcow) & T. Kowalski & $-^{\mathrm{a}}$ & - & n.a. \\
\hline Phomopsis sp. & $08-410$ & Mycelium & France (Haute Saône) & R. Ioos & $-^{\mathrm{a}}$ & - & n.a. \\
\hline $\begin{array}{l}\text { Non-sporulating } \\
\text { fungus }\end{array}$ & $08-483.5$ & Mycelium & France (Haute Saône) & R. Ioos & $-^{\mathrm{a}}$ & - & n.a. \\
\hline $\begin{array}{l}\text { Non-sporulating } \\
\text { fungus }\end{array}$ & $08-1004.4$ & Mycelium & $\begin{array}{l}\text { Switzerland } \\
\quad \text { (Rottenschwill) }\end{array}$ & O. Holdenrieder & $-^{\mathrm{a}}$ & - & n.a. \\
\hline Fraxinus excelsior & FRE1 & twig & $\begin{array}{l}\text { France } \\
\quad \text { (Meurthe et Moselle) }\end{array}$ & INRA & - & - & n.a. \\
\hline
\end{tabular}

n.a.: Not analysed

ITSfru: ITS sequence identical to the ITS sequence of Hymenoscyphus fructigenus retrieved from GenBank database (Accession No. DQ431176.1)

${ }^{\text {a }}$ Results of real-time PCR from Ioos et al. (2009). Fungal strains were the same in both studies

designed to target a ca. $570 \mathrm{bp}$ region of the FG740 gene (Table 3). Finally, two other single-copy genes studied by Aguileta et al. (2008), Mcm7 (MS456) and Tsr1 (MS277), were amplified using primer pairs Mcm7-709for/Mcm7-1447rev and Tsr1-1459for/Tsr12308rev, respectively, designed by Schmitt et al. (2009).

PCR conditions for the CHA-F1/-R2 and the FG740-F/-R primer pairs were the same as described above, except that (i) primer concentrations were increased to $0.3 \mu \mathrm{M}$ for CHA-F1/-R2 and (ii) annealing temperatures were increased to $53^{\circ} \mathrm{C}$ for FG740-F/-R and $65^{\circ} \mathrm{C}$ for CHA-F1/-R2. PCR conditions for the Mcm7-709for/Mcm7-1447rev and Tsr1-1459for/Tsr1-2308rev primers were those applied in Schmitt et al. (2009). In all cases, the PCR products obtained were visualized and sequenced as previously described.

\section{Real-time PCR amplifications}

Amplifications with primer pair and probe Cfrax-F/-R-/P (Ioos et al. 2009) were performed in $15 \mu$ l reaction volumes using the qPCR core kit no ROX (Eurogentec, Seraing, Belgium) and consisting of ultra-pure water, $1 \mathrm{x}$ reaction buffer, $5 \mathrm{mM} \mathrm{MgCl} 2,4 \times 0.2 \mathrm{mM}$ dNTPs, $0.3 \mu \mathrm{M}$ of each primer, $0.1 \mu \mathrm{M}$ of dual-labelled probe, $0.15 \mathrm{U}$ of Uracil-DNA-Glycosylase (UNG), $0.375 \mathrm{U}$ of Hotgoldstar and $2 \mu \mathrm{l}$ of template DNA. The reaction mixture with Halb-F/-R-/P contained 1x qPCR Mastermix no ROX (Eurogentec, Seraing, Belgium), $0.3 \mu \mathrm{M}$ of each primer, $0.1 \mu \mathrm{M}$ of dual-labelled probe, $0.15 \mathrm{U}$ of UNG, $2 \mu \mathrm{l}$ of template DNA and ultra-pure water was added to $15 \mu$ l.

Real-time PCR reactions were carried out on a Rotor-Gene 6200 (Qiagen, Courtaboeuf, France). For both assays, the PCR cycling conditions included an 
Table 3 List of primer pairs and dual-labelled probes developed in this study

\begin{tabular}{lllll}
\hline Name & Sequence $\left(5^{\prime}-3^{\prime}\right)$ & Characteristics & Template DNA region & Product size (bp) \\
\hline Halb-F & TATATTGTTGCTTTAGCAGGTCGC & Real-Time PCR & & 67 \\
Halb-R & ATCCTCTAGCAGGCACGGTC & Real-Time PCR & ITS & \\
Halb-P & YY-CCGGGGCGTTGGCCTCG-BHQ2 & Real-Time PCR & & 570 \\
FG740-F & ATGGTTCGACTCWAACTACCA & Conventional PCR & \multirow{2}{*}{ FG740 gene } & \\
FG740-R & TTGAGGTTGGTYTTCCARATGT & Conventional PCR & & $780 / 781$ \\
CHA-F1 & GGTTTCACTCCTGAACAACGA & Conventional PCR & ITS & \\
CHA-R2 & GACCCTATCGCGAGAAGAATTA & Conventional PCR & & \\
\hline
\end{tabular}

initial step for $\mathrm{UNG}$ activation for $2 \mathrm{~min}$ at $50^{\circ} \mathrm{C}$, a HotGoldStar activation step for $10 \mathrm{~min}$ at $95^{\circ} \mathrm{C}$ followed by 35 cycles of denaturation at $95^{\circ} \mathrm{C}$ for $15 \mathrm{~s}$, and annealing and elongation at $65^{\circ} \mathrm{C}$ for $55 \mathrm{~s}$. The $\mathrm{Ct}$ value for each reaction was determined using the Rotor-Gene software version 1.7 .75 with a normalized fluorescence set at 0.02 .

Sequences, size products and specificity of all primer pairs and probe developed in this study are indicated in Table 3.

Presence of $H$. albidus on symptomatic ash trees in France

Presence of ash decline putatively associated with H. pseudoalbidus has been monitored during 20082009 throughout France by the Département de la Santé des Forêts (DSF). Each time symptoms similar to those caused by $H$. pseudoalbidus were observed, either in the WF or OF sites, samples of twigs or branches with necrosis were collected from young or mature trees by the DSF and sent to the Laboratoire National de la Protection des Végétaux (LNPV) in Nancy for diagnostic PCR. Presence/absence of the pathogen was confirmed using the real-time PCR test developed by Ioos et al. (2009) on more than 300 symptomatic samples (Fig. 1a). Since this test does not allow the detection of strains with $\operatorname{ITS}_{\mathrm{B}}$, the survey was further completed by using the primer pair and probe Halb-F/-R/-P developed in this study, in order to test for the presence/absence of $H$. albidus on symptomatic ash trees. A total of 63 samples from symptomatic $F$. excelsior twigs or buds for which presence of $H$. pseudoalbidus could not be confirmed in 2009, and 12 additional samples randomly taken from those for which presence of $H$. pseudoalbidus was confirmed, were assessed.

\section{Results}

Sequences present in the OF and WF populations for ITS and single-copy genes

Altogether, 48, 30, 9, and 6 sequences were analysed for the ITS and the FG740, Mcm7 and Tsr1 genes, respectively. For each locus amplified, two different sequence types were obtained, thereafter referred to as ITS $_{\mathrm{A}} / \mathrm{ITS}_{\mathrm{B}}, \mathrm{FG} 740_{\mathrm{A}} / \mathrm{FG} 740_{\mathrm{B}}, \mathrm{Mcm} 7_{\mathrm{A}} / \mathrm{Mcm} 7_{\mathrm{B}}$ and $\operatorname{Tsr}_{\mathrm{A}} / \operatorname{Tsr}_{\mathrm{B}}$, respectively (Tables 1 and 2).

ITS $_{\mathrm{A}}$ and ITS $_{\mathrm{B}}$ sequences had a 909 and $910 \mathrm{bp}$ size, respectively, and differed at 15 nucleotide positions (1.6\%): 14 mutations and 1 deletion (Table 4). Both sequences exhibited an insertion of $321 \mathrm{bp}$ at the $3^{\prime}$ end of the $18 \mathrm{~S}$ gene located between ITS1F and ITS1 priming sites. This insertion corresponds to a type I intron, which is very common at this position in the $18 \mathrm{~S}$ rDNA gene in many Ascomycetes, corresponding to the 1506 bp position in the reference Escherichia coli 16S rDNA gene (Feau et al. 2007). Since this intron was absent in Hymenoscyphus scutula, it was used to design H. pseudoalbidus-specific primers by Johansson et al. (2010). Most polymorphisms (47\%) were located in the ITS1 region (Table 4), 27\% (4 out of 15 ) in the $18 \mathrm{~S}$ intron and $27 \%$ in the ITS2. The size of the ITS1-5,8S- ITS2 region obtained using ITS1/ITS4 primers was $551-552 \mathrm{bp}$. Based only on this region, the difference between ITS $_{\mathrm{A}}$ and ITS $_{\mathrm{B}}$ was increased to $2 \%$. All ITS $\mathrm{I}_{\mathrm{A}}$ sequences were found to be $100 \%$ identical; similarly, all ITS $\mathrm{B}_{\mathrm{B}}$ sequences were strictly identical.

For the FG740 gene sequences, there was a polymorphism of about $1.9 \%$ (11 out of $570 \mathrm{bp}$ ) between the sequence types $\mathrm{FG} 740_{\mathrm{A}}$ and $\mathrm{FG} 740_{\mathrm{B}}$. A $100 \%$ identity was observed within the $\mathrm{FG} 740_{\mathrm{A}}$ and the $\mathrm{FG} 740_{\mathrm{B}}$ sequences. All the isolates or samples exhibiting an $\mathrm{ITS}_{\mathrm{A}}$ sequence also exhibited a FG740 
Table 4 Characteristics of the ITS sequences obtained with primer pair ITS1F/ITS4 and of the single-copy gene sequences

\begin{tabular}{|c|c|c|c|c|}
\hline & $\begin{array}{l}\text { Product } \\
\text { size }(\mathrm{bp})\end{array}$ & $\begin{array}{l}\text { Number of mismatches/gap } \\
\text { between A and B sequences }\end{array}$ & $\begin{array}{l}\text { Identity between A } \\
\text { and B sequences }\end{array}$ & $\begin{array}{l}\text { Location of polymorphisms } \\
\left.\text { (number of bp, } 5^{\prime}-3^{\prime}\right) . \text { In bold, gap }\end{array}$ \\
\hline $\begin{array}{l}\operatorname{ITS}_{\mathrm{A}} \\
\operatorname{ITS}_{\mathrm{B}}\end{array}$ & $\begin{array}{l}909 \\
910\end{array}$ & $14 / 1$ & $98.4 \%$ & $\begin{array}{c}56-90-182-269-460-461-463-470- \\
484-500-607-738-744-819-833\end{array}$ \\
\hline $\begin{array}{l}\text { FG740 A } \\
\text { FG740 }\end{array}$ & $\begin{array}{l}570 \\
570\end{array}$ & $11 / 0$ & $98.1 \%$ & $\begin{array}{l}286-295-340-382-400-424-438-448- \\
\quad 469-496-505\end{array}$ \\
\hline $\begin{array}{l}\mathrm{Mcm}_{\mathrm{A}} \\
\mathrm{Mcm} 7_{\mathrm{B}}\end{array}$ & $\begin{array}{l}759 \\
759\end{array}$ & $16 / 0$ & $97.9 \%$ & $\begin{array}{l}75-102-180-195-228-279-285-327- \\
339-465-489-504-516-537-573-672\end{array}$ \\
\hline $\begin{array}{l}\operatorname{Tsr}_{\mathrm{A}} \\
\operatorname{Tsr}_{\mathrm{B}}\end{array}$ & $\begin{array}{l}678 \\
678\end{array}$ & $26 / 0$ & $96.2 \%$ & $\begin{array}{l}109-127-136-142-238-241-268-280- \\
293-298-310-325-340-349-353-376- \\
385-475-508-532-553-559-571-601- \\
607-655\end{array}$ \\
\hline
\end{tabular}

$100 \%$ identity was found within the type A and type B sequences

sequence; similarly, those with an $\operatorname{ITS}_{\mathrm{B}}$ sequence had a $\mathrm{FG} 740_{\mathrm{B}}$ sequence (Table 1). All isolates or samples originating from OF sites exhibited an ITS $_{B}$ and a FG740 $\mathrm{B}$ sequence. Conversely, the isolates or samples collected in WF sites were distributed in both sequence type groups. The isolates originating from cankers on infected seedlings had ITS $_{\mathrm{A}}$ and FG740 $A$ sequences, whereas those from rachis or apothecia had ITS $\mathrm{A}_{\mathrm{A}} / \mathrm{FG} 740_{\mathrm{A}}$ or $\mathrm{ITS}_{\mathrm{B}} / \mathrm{FG} 740_{\mathrm{B}}$ sequence combinations. In Amage, the two different sequence combinations were obtained from the same ash stand.

Similarly, for the Mcm7 and the Tsr1 genes, two different sequences types were obtained: $\mathrm{Mcm} 7_{\mathrm{A}}$ / $\mathrm{Mcm} 7_{\mathrm{B}}$ and $\mathrm{Tsr}_{\mathrm{A}} / \mathrm{Tsr}_{\mathrm{B}}$ which had a $759-678$ bp size and $2.1-3.8 \%$ bp polymorphism, respectively (Table 4). All the isolates exhibiting $\mathrm{ITS}_{\mathrm{A}} / \mathrm{FG} \mathrm{F40} \mathrm{A}$ sequences also exhibited $\mathrm{Mcm} 7_{\mathrm{A}} / \mathrm{Tsr}_{\mathrm{A}}$ sequences; those with $\mathrm{ITS}_{\mathrm{B}} / \mathrm{FG} 740_{\mathrm{B}}$ sequence had $\mathrm{Mcm} 7_{\mathrm{B}} / \mathrm{Tsr} 1_{\mathrm{B}}$ sequences (Table 1). A $100 \%$ identity was observed within each sequence type.

For samples which did not produce an amplicon of the expected size with the ITS1F/ITS4 primer pair, a portion of the ITS sequence was successfully obtained with the CHA-F1/-R2 primer pair which proved to be more specific (i.e. samples GOU-M-2, MER-M-14, ROB-P-3, ROB-P-4, ROB-P-5, VAN-6, VAN-13, $781 \mathrm{bp}$ and sample 2004, 510 bp) or the Halb-F/-R primer pair (samples 1604 and ThD0207254370, $67 \mathrm{bp}$ ). The sequenced regions contained respectively 13, 8 and 6 polymorphisms out of the 15 known in the 910 bp ITS sequence. In the three cases, the partial sequences obtained were $100 \%$ identical to the corresponding ITS $_{\mathrm{A}}$ (GOU-M-2, MER-M-14) or ITS (all the other samples, including the herbarium type specimens No. 1604 and 2004) sequences and the relationship with the FG740 sequence type was confirmed, excluding herbarium specimens for which PCR amplification of the FG740 gene was unsuccessful (Table 1).

Specificity of real-time PCR assay using primers/probe Halb-F/-R/-P

The primer pair and dual-labelled probe Halb-F/-R/-P were tested on a wide collection of isolates or samples (Table 2). This real-time PCR assay yielded a positive signal for all samples containing an ITS $_{B}$ sequence and no positive signal for samples containing an ITS $_{\mathrm{A}}$ sequence, i.e. all strains originating from cankers. The specificity of the primers/probe combination was checked on a collection of saprophytic or endophytic fungi sharing the same ecological niche and on Fraxinus excelsior DNA. No cross-reaction was observed (Table 2). The Halb-F/-R/-P combination was also successfully used to detect ITS $_{B}$ sequence from DNA extracted from naturally infected rachis or from apothecia (Ct values ranging from 19 to 23.3 for DNA extracts from one fresh apothecia). Finally, DNA extracted from 3 to 4 apothecia of the herbarium type specimens (No. 1604 and 2004) resulted in $\mathrm{Ct}$ values ranging from 23.6 to 25.6 using Halb-F/-R/-P, whereas no signal was detected using Cfrax-F/-R/-P. 
Presence of $H$. albidus on symptomatic ash trees in France

A set of samples collected during the survey carried out by the DSF in 2009 was analysed using the primers/probe Halb-F/-R/-P combination in order to determine whether isolates containing the $\operatorname{ITS}_{\mathrm{B}}$ sequence type were common on symptomatic tissues from declining ash trees in France. Altogether, this PCR assay yielded a positive signal for only one out of 63 samples that initially were negative with primers/probe Cfrax-F/-R-P. No positive signal was obtained for the 12 samples that were found positive with primers/probe Cfrax-F/-R-P (Fig. 1b). Thus, isolates containing the $\mathrm{ITS}_{\mathrm{B}}$ sequence were not common in France on diseased twigs of declining ashes during the year 2009 .

Pathogenicity test

All isolates collected from WF sites and used for inoculation were of the type $\mathrm{A}$, i.e. $\mathrm{ITS}_{\mathrm{A}} / \mathrm{FG} 740_{\mathrm{A}} /$ $\mathrm{Mcm} 7_{\mathrm{A}} / \mathrm{Tsr}_{\mathrm{A}}$ sequence type, based on the real-time PCR tests used in this study (Cfrax-F-/-R/-P and Halb-F-/-R/-P). Conversely, all isolates from $\mathrm{OF}$ sites were of the type $\mathrm{B}$, i.e. $\mathrm{ITS}_{\mathrm{B}} / \mathrm{FG} \mathrm{F40} 0_{\mathrm{B}} / \mathrm{Mcm} 7_{\mathrm{B}} /$ $\mathrm{Tsr}_{\mathrm{B}}$ sequence type, based on these real-time PCR tests.

When lesions significantly larger than the control were observed in the seedling inner bark, the pathogen had quickly colonized the stem inner pit and spread to the entire wood section at the inoculation point. No seedlings were girdled at the observation time although many were very close to. This occurred in most of the ash seedlings inoculated with isolates from WF sites, with lesions length of 19-330 mm ( $83 \pm 16 \mathrm{~mm}$, significantly different from the control, Pvalue $<0.001$ ). By contrast, lesions on seedlings inoculated with isolates from $\mathrm{OF}$ sites were not significantly different from the control ( $P$ value $=0.99$, length $18.2 \pm 7.5 \mathrm{~mm}$ versus $18.9 \pm$ $9.9 \mathrm{~mm}$ for control). Thus, isolates from $\mathrm{OF}$ sites which all were of the $\mathrm{ITS}_{\mathrm{B}} / \mathrm{FG} 740_{\mathrm{B}}$ type showed no pathogenicity towards ash seedlings (Fig. 2). No significant differences were evidenced between the tested WF populations in the lesion length induced on the inoculated ash seedlings $(F=1.5, P$ value $=0.144)$. All the type A isolates from rachis/apothecia or canker exhibited the same pathogenicity level.

\section{Discussion}

Our results showed that two different types of Hymenoscyphus sp. strains were associated with ash in France in 2009. The type A isolates exhibited $\mathrm{ITS}_{\mathrm{A}} / \mathrm{FG} 740_{\mathrm{A}} / \mathrm{Mcm} 7_{\mathrm{A}} / \mathrm{Tsr}_{\mathrm{A}}$ sequences and were present only in the area of Northeastern France where H. pseudoalbidus associated decline has been recorded. These isolates were collected either from cankers on affected trees or from apothecia on ash rachis in the litter of ash stands affected by H. pseudoalbidus. Furthermore, these isolates exhibited a strong pathogenicity in artificial inoculation tests. The type $\mathrm{B}$ isolates exhibited $\mathrm{ITS}_{\mathrm{B}} / \mathrm{FG} 740_{\mathrm{B}} / \mathrm{Mcm} 7_{\mathrm{B}} / \mathrm{Tsr}_{\mathrm{B}}$ sequences and were present throughout Northern France, both in areas where $H$. pseudoalbidus associated decline has been recorded or not. They were isolated only from apothecia or rachis in the litter but never from canker and showed no pathogenicity toward ash seedling in inoculation tests.

Based on the sequence data and the very different biology - pathogenicity vs. saprotrophy - the type A and $\mathrm{B}$ isolates are clearly different species. As the reference strain $\mathrm{N}^{\circ} 2112$ belongs to the pathogen type A isolates, this type corresponds to H. pseudoalbidus, whose anamorphic stage is Chalara fraxinea (Queloz et al. 2010). The type $\mathrm{B}$ corresponds to $H$. albidus, since the original type specimens collected by Roberge in 1850 near Caen and used for the species description (Desmazières 1851) correspond to type B. Queloz et al. (2010) presented molecular evidence for separating $H$. albidus and $H$. pseudoalbidus based on data from three loci (ITS, calmodulin gene and elongation factor 1- $\alpha$ ) and ISSR-fingerprinting. Our study based on the ITS sequences and three single-copy gene sequences and which included the original type specimen of $H$. albidus provided a clear confirmation of the results of Queloz et al. (2010).

This study brings new findings on the origin of the ash decline associated to $H$. pseudoalbidus. Our results strongly suggest that the emergence of H. pseudoalbidus in France in 2008 is linked to the recent arrival of the pathogen in Northeastern France. The absence of $H$. pseudoalbidus from France before 2008 cannot be strictly demonstrated, since very few samples from apothecia on ash rachis are available from the pre-2008 period. However, the absence of $H$. pseudoalbidus from most of France in 2009, the strong link between its 
Fig. 2 Aggressiveness of WF and OF sites isolates. Ai, Ainvelle; Ba, Bauley; Bau, Baume-les-Dames, Fo, Fontenoy-le-Château; Gi, Girecourt; La, Lamguimberg; Lo, Louze; Me, Mersuay; Mi, Mignéville; Mo, Mont-Dieu; Pl, Plestin-lesGrèves; Se, Seichamps; Vi, Visoncourt. The number above the bar is the number of isolates tested per sites. Open bars, WF sites; striped bars, OF sites; black bar, negative control

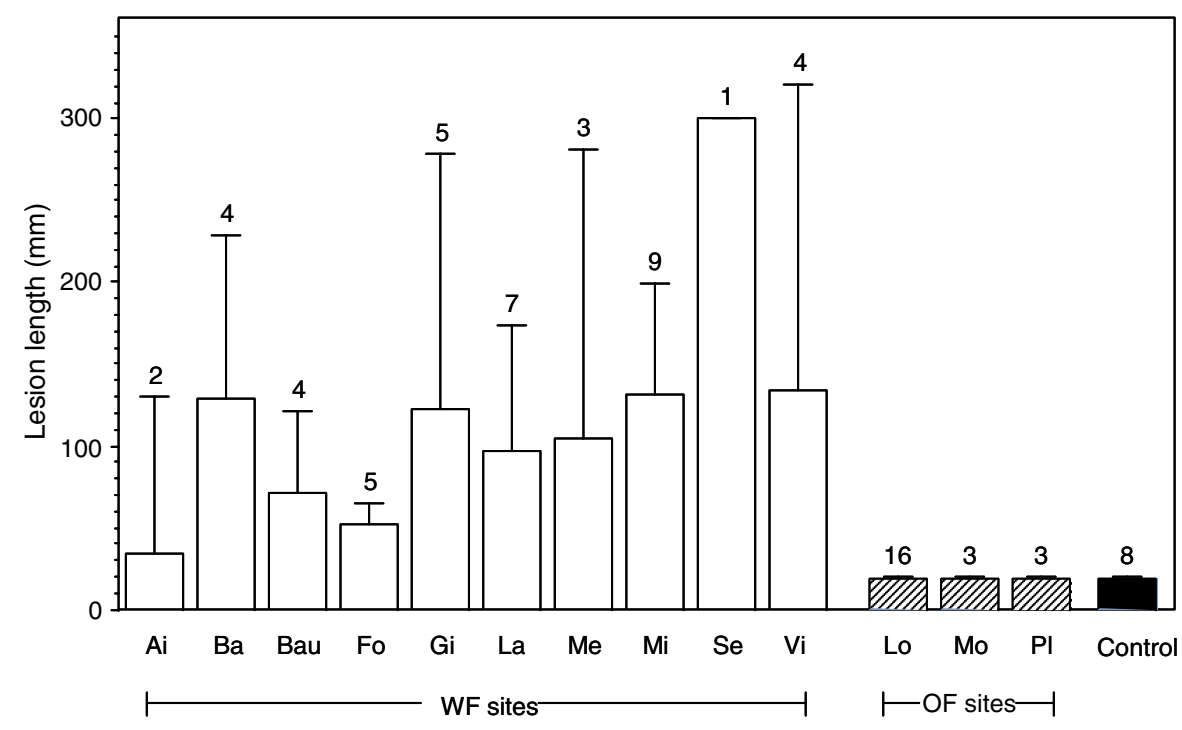

presence on ash rachis and severe decline associated to H. pseudoalbidus, and the sudden emergence of this ash decline in Northeastern France in 2008, altogether strongly suggest that this species is an invasive newcomer, probably arriving from Eastern Europe, where the disease was first reported (Kowalski 2006). The fact that isolate No. 2112 from Poland belongs to type A confirms this last hypothesis. Nevertheless, Queloz et al. (2010) showed that two herbarium specimens collected in 1978 and 1987 from Switzerland could be assigned to $H$. pseudoalbidus while ash decline was not reported at that time. Presence of such an emerging pathogen 20 or 30 years ago in Switzerland is surprising as the pathogen appears to be presently absent from most of France. The date of arrival of the pathogen remains thus unclear and needs to be better documented.

In contrast, $H$. albidus is a non-pathogenic saprotrophic species developing on ash rachis in the litter and is clearly not involved in the ash decline. Survey for this fungal species over France in 2009 failed to detect it on affected twigs of symptomatic ash trees in all but one case. Symptomatic $F$. excelsior samples for which neither $H$. pseudoalbidus nor H. albidus were detected using specific primer pairs (62 out of more than 300) were probably due to abiotic damages or other pathogenic fungi. The future of $H$. albidus might be endangered by the $H$. pseudoalbidus invasion. Indeed, while they do not have exactly the same ecological niche, $H$. albidus being absent from twigs, both species are found on leaf rachis in the litter. The presence of $H$. pseudoalbidus on the rachis in the litter may be abundant (data not shown) and the fungus is able to colonise rachis early, while leaves are still alive on trees. We might thus hypothesize that $H$. pseudoalbidus could replace $H$. albidus on the rachis niche. Alternatively, $H$. albidus could be able to compete and limit the inoculum production of $H$. pseudoalbidus. In some sites, the two Hymenoscyphus species were found together; however, the presence of $H$. pseudoalbidus was probably very recent and very few apothecia sampled were of $H$. albidus. The competition outcome in these sites will be worthwhile to document. The primer/probe combinations Halb-F/-R/-P (developed in this study) and Cfrax-F/-R/-P (Ioos et al. 2009) were shown to be specific for $H$. albidus and H. pseudoalbidus, respectively and would thus be very useful to survey this competition.

Complexes of cryptic species have been increasingly reported in plant pathology. In forest pathology, well-documented cases are the Dothistroma septosporum / D. pini on pine (Barnes et al. 2004) and the powdery mildews on oak (Mougou et al. 2008). When a complex of cryptic species occurs in an emerging disease, such as Dothistroma needle blight or H. pseudoalbidus ash decline, it strongly clouds the issues of emergence, because it can be difficult to determine whether or not the epidemic is caused by an invasive newcomer. For example, although D. septosporum has been already present in France for a long time, the emergence of Dothistroma needle blight in France in the mid 1990s could be related to the introduction of $D$. pini. Indeed, this species, previously 
mentioned as absent from Europe, is now widely distributed in France (Ioos et al. 2010). As this species is not morphologically different from $D$. septosporum, it is unfortunately difficult to determine a posteriori when $D$. pini was introduced in France. Thus, when the emergence is well documented as for the H. pseudoalbidus ash decline, it is crucial to well describe the fungal species present within/outside the area of emergence. Alternatively, the study of herbarium specimens can be very useful. For example, using herbarium samples collected over the two last centuries, Antonovics et al. (2003) documented the invasion of North America by Microbotryum violaceum which causes the anthersmut disease on Silene spp. Similarly, a retrospective study of old herbarium specimens could definitively clarify the past status of $H$. pseudoalbidus in Eastern France if enough specimens are available.

Acknowledgements We are grateful to Anne Derycke (DSF), Michel Hairaud, Rémy Péan and Jean Pierre Dechaume who indicated us sites with presence of $H$. albidus in Western and Central France. We would like to thank Jean-Philippe Rioult, from the Caen Herbarium (CN)-Université de Caen BasseNormandie (UCBN) for the historical herbarium type specimens of $H$. albidus and Tadeusz Kowalski who provided isolates from Poland. This work greatly depended on the technical assistance of Jocelyn Gueny. We also thank Agathe Vialle (Canadian Forest Service, Quebec) for sharing a DNA extraction method for herbarium samples, and the Département de la Santé des Forêts for the maps of $H$. pseudoalbidus presence in France. This study was supported by grants from the Département de la Santé des Forêts and the Agence Nationale de la Recherche, contract number ANR 07-BDIV003 (Emerfundis project).

\section{References}

Aguileta, G., Marthey, S., Chiapello, H., Lebrun, M. H., Rodolphe, F., Fournier, E., et al. (2008). Assessing the performance of single-copy genes for recovering robust phylogenies. Systematic Biology, 57, 613-627.

Anagnostakis, S. L. (1987). Chestnut blight: the classical problem of an introduced pathogen. Mycologia, 79, 23-37.

Anderson, P. K., Cunningham, A. A., Patel, N. G., Morales, F. J., Epstein, P. R., \& Daszak, P. (2004). Emerging infectious diseases of plants: pathogen pollution, climate change and agrotechnology drivers. Trends in Ecology and Evolution, 19, 535-544.

Antonovics, J., Hood, M. E., Thrall, P. H., Abrams, J. Y., \& Duthie, G. M. (2003). Herbarium studies on the distribution of anther-smut fungus (Microbotryum violaceum) and Silene species (Caryophyllaceae) in the Eastern United States. American Journal of Botany, 90, 1522-1531.
Bakys, R., Vasaitis, R., Barklund, P., Thomsen, I. M., \& Stenlid, J. (2009). Occurrence and pathogenicity of fungi in necrotic and non-symptomatic shoots of declining common ash (Fraxinus excelsior) in Sweden. European Journal of Forest Research, 128, 51-60.

Barnes, I., Crous, P. W., Wingfield, B. D., \& Wingfield, M. J. (2004). Multigene phylogenies reveal that red band needle blight of Pinus is caused by two distinct species of Dothistroma, D. septosporum and D. pini. Studies in Mycology, 50, 551-565.

Chandelier, A., André, F., \& Laurent, F. (2010). Detection of Chalara fraxinea in common ash (Fraxinus excelsior) using real time PCR. Forest Pathology, 40, 87-95.

Desmazières, J. B. (1851). Peziza (Phialea cyathoidea) albida. Annales des Sciences Naturelles, Botanique, Série 3, 16, 323-324

Desprez-Loustau, M. L., Robin, C., Buée, M., Courtecuisse, R., Garbaye, J., Suffert, F., et al. (2007). The fungal dimension of biological invasions. Trends in Ecology and Evolution, 22, 472-480.

Desprez-Loustau, M. L., Courtecuisse, R., Robin, C., Husson, C., Moreau, P. A., Blancard, et al. (2010). Species diversity and drivers of spread of alien fungi (sensu lato) in Europe with a particular focus on France. Biological Invasions, 12, 157-172.

Feau, N. (2010, August). Fishing single copy genes out of sequenced genomes for multilocus phylogenetics in nonmodel fungi. Poster P1.84. 9th International Mycological Congress, Edimbourg.

Feau, N., Hamelin, R. C., \& Bernier, L. (2007). Variability of nuclear SSU-rDNA group introns within Septoria species: incongruence with host sequence phylogenies. Journal of Molecular Evolution, 64, 489-499.

Gardes, M., \& Bruns, T. D. (1993). ITS primers with enhanced specificity for basidiomycetes-application to the identification of mycorrhizae and rusts. Molecular Ecology, 2, 113-118.

Ioos, R., Andrieux, A., Marçais, B., \& Frey, P. (2006). Genetic characterization of the natural hybrid species Phytophthora alni as inferred from nuclear and mitochondrial DNA analyses. Fungal Genetics and Biology, 43, 511529 .

Ioos, R., Kowalski, T., Husson, C., \& Holdenrieder, O. (2009). Rapid in planta detection of Chalara fraxinea by a realtime PCR assay using a dual-labelled probe. European Journal of Plant Pathology, 125, 329-335.

Ioos, R., Fabre, B., Saurat, C., Fourrier, C., Frey, P., \& Marçais, B. (2010). Development, comparison, and validation of real-time and conventional PCR tools for the detection of the fungal pathogens causing brown spot and red band needle blights of pine. Phytopathology, 100, 105-114.

Johansson, S. B. K., Vasaitis, R., Ihrmark, K., Barklund, P., \& Stenlid, J. (2010). Detection of Chalara fraxinea from tissue of Fraxinus excelsior using species-specific ITS primers. Forest Pathology, 40, 111-115.

Kowalski, T. (2006). Chalara fraxinea sp. nov. associated with dieback of ash (Fraxinus excelsior) in Poland. Forest Pathology, 36, 264-270.

Kowalski, T., \& Holdenrieder, O. (2009). The teleomorph of Chalara fraxinea, the causal agent of ash dieback. Forest Pathology, 39, 304-308. 
Marçais, B., Bergot, M., Perarnaud, V., Levy, A., \& DesprezLoustau, M. L. (2004). Prediction and mapping of the impact of winter temperatures on the development of $P$. cinnamomi induced cankers on red and pedunculate oak. Phytopathology, 94, 826-831.

Marthey, S., Aguileta, G., Rodolphe, F., Gendrault, A., Giraud, T., Fournier, E., et al. (2008). FUNYBASE: a FUNgal phYlogenomic dataBASE. BMC Bioinformatics, 9, 456.

Mougou, A., Dutech, C., \& Desprez-Loustau, M. L. (2008). New insights into the identity and origin of the causal agent of oak powdery mildew in Europe. Forest Pathology, 38, 275-287.

Queloz, V., Grünig, C. R., Berndt, R., Kowalski, T., Sieber, T. N., \& Holdenrieder, O. (2010). Cryptic speciation in Hymenoscyphus albidus. Forest Pathology. doi:10.1111/ j.1439-0329.2010.00645.x (in press).

Rozen, S., \& Skaletsky, H. (2000). PRIMER3 on the WWW for general users and for biologists programmers. In S. Krawetz \& S. Misener (Eds.), Bioinformatics methods and protocols: Methods in molecular biology (pp. 365-386). Totowa: Humana.
Schmitt, I., Crespo, A., Divakar, P. K., Fankhauser, J. D., Herman-Sackett, E., Kalb, K., et al. (2009). New primers for promising single-copy genes in fungal phylogenetics and systematics. Persoonia, 23, 35-40.

Schumacher, J., Kehr, R., \& Leonhard, S. (2010). Mycological and histological investigations of Fraxinus excelsior nursery saplings naturally infected by Chalara fraxinea. Forest Pathololy, 40, 419-429.

Weste, G., \& Marks, G. C. (1987). The biology of Phytophthora cinnamomi in Australasian forests. Annual Review of Phytopathology, 25, 207-229.

White, T. M., Bruns, T., Lee, S., \& Taylor, J. (1990). Amplification and direct sequencing of fungal ribosomal RNA genes for phylogenetics. In M. A. Innis, D. H. Gelfand, J. J. Sninsky, \& T. J. White (Eds.), PCR protocols: $A$ guide to methods and applications (pp. 315-322). New York: Academic.

Woods, A., Coates, D. K., \& Hamann, A. (2005). Is an unprecedented Dothistroma Needle Blight epidemic related to climate change? BioScience, 55, 761-769. 